\title{
Seblang : Sebuah Ritual Tari Di Desa Olehsari Kecamatan Glagah Kabupaten Banyuwangi Jawa Timur Tahun 1990-2017
}

\author{
Reinaldo Fahmi Zackaria*, I Wayan Tagel Eddy, Ida Ayu Wirasmini Sidemen \\ Prodi Sejarah, Fakultas Ilmu Budaya, Unud \\ [reinaldofahmi26@yahoo.co.id], [tageleddy58@gmail.com], \\ [idaayuwirasmini@gmail.com] \\ *Corresponding Author
}

\begin{abstract}
This study discussed about the Seblang rituals in the village of Olehsari which tells about the emergence of the Seblang ritual, the process of carrying out the Seblang ritual, and how the effects of the Seblang ritual on the social and cultural conditions of the village of Olehsari were affected. The purpose of this study was to find out in depth about the history and life of Seblang culture from 1990 to 2017 and how the impact of the Seblang ritual on the social and cultural conditions of the village of Olehsari. Moreover, this study had three research questions proposed, the answers of which were sought using the methodology of cultural history from Kuntowijoyo. The method used is also assisted by historical theories from Ida Bagus Sidemen. Based on the data analysis, it was concluded that the appearance of the Seblang ritual originated from a pagebluk that attacked the slopes of Mount Ijen, which resulted many disasters, sick people, and many failed crops. Since humans in ancient times, or traditional humans, believed in the existence of mystical things, the consider pagebluk is caused due to a lack of balance between nature and humans. For this reason, the Seblang ritual exist. It is through this intermediary of the Seblang ritual that the community of Olehsari hopes that the disaster will end in the village of Olehsari.
\end{abstract}

Keywords: seblang, ritual, pagebluk

\begin{abstract}
Abstrak
Studi ini mengkaji mengenai ritual Seblang di desa Olehsari yang menceritakan mengenai kemunculan ritual Seblang, proses pelaksanaan ritual Seblang, serta bagaimana dampak dari adanya ritual Seblang terhadap keadaan sosial dan budaya masyarakat desa Olehsari. Tujuan dari penelitian ini ialah untuk mengetahui secara mendalam tentang sejarah dan kehidupan kebudayaan Seblang pada tahun 1990 sampai 2017 dan bagaimana dampak dari adanya ritual Seblang terhadap keadaan sosial dan budaya masyarakat desa Olehsari. Selanjutnya dalam penelitian ini terdapat tiga pertanyaan penelitian yang diajukan, yang jawabannya dicari dengan menggunakan metodologi sejarah kebudayaan dari Kuntowijoyo. Metode yang digunakan pula juga dibantu oleh teori-teori sejarah dari Ida Bagus Sidemen. Berdasarkan analisis data yang dilakukan, diperoleh kesimpulan bahwa kemunculan ritual Seblang ini berawal dari adanya suatu pagebluk yang menyerang lereng gunung Ijen, yang mengakibatkan banyak terjadi musibah, seperti, orang sakit, serta banyak hasil panen yang gagal. Karena mengingat bahwa manusia pada zaman dahulu, atau manusia tradisional masih percaya akan adanya hal mistis dan menganggap terjadinya pagebluk bisa jadi karena kurangnya keseimbangan antara
\end{abstract}


alam dengan manusia. Untuk itu, muncullah ritual Seblang. Melalui perantara ritual Seblang inilah masyarakat desa Olehsari mengharap akan berakhirnya musibah yang terjadi di desa Olehsari.

Kata kunci: seblang, ritual, pagebluk

\section{Latar Belakang}

Negara Indonesia adalah suatu negara yang kaya akan kehidupan kebudayaannya. Setiap budaya daerah seperti adat, bahasa, dan kepercayaan, memiliki ciri khas tersendiri, termasuk kesenian tari dan musik. Kesenian yang dimiliki oleh nusantara ini telah berkembang sesuai dengan wilayah masing- masing, beda pulau tentunya juga beda kesenian, yang kemudian dilestarikan secara turun temurun agar kesenian tersebut selalu terjaga dan tetap lestari keberadaannya. (Margana, 2012)

Mengenai kebudayaan yang telah ada sejak turun temurun, sangat berkaitan erat dengan satu daerah yang berada di Jawa Timur, yang juga telah memiliki banyak kebudayaan yang sudah melekat di masyarakat, daerah tersebutadalah

Banyuwangi. Secara historis, Banyuwangi memiliki karakter khas dalam bidang pertumbuhan sosial dan budaya. Banyuwangi juga sebagai tempat bertemunya beragam budaya. Terdapat berbagai macam etnis di Banyuwangi, seperti etnis Madura dan Jawa. Tentu hal ini membawa budaya khasnya masingmasing. Tentunya juga, di setiap wilayah memiliki keunikan masing- masing yang berbeda, akan tetapi juga akan saling berkaitan satu dengan lainnya (Margana, 2012). Membahas mengenai kehidupan kebudayaan, tentunya tidak akan lepas dengan hal keagamaan maupun keritualan. Ritual atau upacara adat itu sendiri adalah salah satu bentuk kegiatan masyarakat tradisional yang masih dianggap memiliki hubungan- hubungan yang cukup relevan bagi kebutuhan masyarakat pendukungnya di Indonesia, termasuk juga di kabupaten Banyuwangi. Selain sebagai usaha manusia untuk berhubungan dengan dahnyang atau mahluk yang tidak kasat mata, ritual merupakan perwujudan kemampuan manusia untuk menyesuaikan diri terhadap alam atau lingkungannya dalam arti luas(Avina).

Sebagai wilayah yang multikultural, Banyuwangi sangat kaya akan budaya dan adat istiadatnya. Akan tetapi, pada kenyataannya masyarakat yang mendiami wilayah Banyuwangi atau orang Banyuwangi asli adalah mereka yang disebut suku Osing. Jadi, orang Banyuwangi adalah orang Osing. Dalam bahasa Osing, kata Osing (dibaca Using) itu sendiri berarti "tidak", dan kata Osing ini mewakili keberadaan orang Osing yang ada di Banyuwangi (Sutarto). Dengan mengingat keragaman etnis yag mendiami wilayah Banyuwangi, tentunya juga terdapat berbagai macam kebudayaan maupun kegiatan keritualan. Salah satunya ialah Seblang. Ritual Seblang merupakan suatu kegiatan yang difungsikan sebagai ritual bersih desa dan tolak bala bagi masyarakat yang berada di Desa Olehsari.

Penulisan mengenai ritual Seblang ini, penulis lebih berfokus pada latarbelakang kemunculan ritual Seblang yang dapat memberikan dampak terhadap keadaan sosial dan budaya masyarakat DesaOlehsari.

\section{Pokok Permasalahan}

a) Apa yang melatarbelakangi munculnya ritual Seblang di Desa Olehsari?

b) Bagaimana proses pelaksanaan ritual Seblang di Desa Olehsari?

c) Apa dampak dari pelaksanaan ritual Seblang bagi masyarakat Desa Olehsari? 


\section{Tujuan Penelitian}

a) Untuk mengetahui secara mendalam tentang sejarah dan kehidupan kebudayaan Seblang pada ahun 1990-2017, serta dapat menambah khasanah ilmu pengetahuan bagi masyarakat umum maupun mahasiswa tentang Seblang.

b) Untuk mengetahui dampak yang dihasilkan oleh ritual Seblang terhadap penduduk Desa Olehsari.

\section{Metode Penelitian}

Adapun metode yang digunakan dalam penelitian ini terdiri dari beberapa tahapan. Tahap Pertama yaitu teknik pengumpulan data dilakukan dengan cara observasi, wawancara, dan studi kepustakaan. Data-data tersebut dapat bersumber dari naskah, wawancara, catatan lapangan, maupun sebuah dokumen yang kemudian dideskripsikan, dirangkai, serta disusun secara sistematis sehingga dapat memberikan kejelasan terhadap kenyataan atau realitas dari suatu permasalahan yang akan diteliti. Tahap kedua yaitu melakukan kritik terhadap sumber-sumber yang didapatkan dari narasumber di lapangan. Kritik di dalam metode sejarah di bagi menjadi dua bagian tertentu yaitu "kritik ekstren" dan "kritik intern" (Kuntowijoyo, 2003). Kemudian data yang telah terkumpul selanjutnya dikembangkan dengan menggunakan teori sejarah.

\section{Hasil dan Pembahasan}

\subsection{Latar Belakang Munculnya Ritual Seblang}

Mengkaji mengenai ritual Seblang yang sejatinya berada di dalam kehidupan masyarakat Osing, tentunya tidak pernah lepas dari satu desa yang bernama Olehsari. Dengan topografi wilayah yang mayoritas berbudaya agraris, tentunya masyarakat yang berdiam di desa ini juga mengandalkan hasil pertanian guna mempertahankan hidupnya.

Hasil pertanian yang melimpah ini, dianggap oleh masyarakat Desa Olehsari sebagai rezeki dan berkah dari Tuhan serta para mahluk yang tidak kasat mata yang juga senantiasa menjaga dan menyeimbangkan keadaan alam. Agar hasil bumi Desa Olehsari semakin meningkat, serta dijauhkan dari musibah atau bencana, untuk itu warga Olehsari selalu melaksanakan ritual ini. Ritual Seblang merupakan bentuk ucapan terimakasih kepada Sang Pencipta atas kesuburan dan hasil pertanian yang tetapmeilmpah.

Dalam hal ini, masyarakat yang berada di Desa Olehsari dalam mengharapkan hasrat keinginan untuk mencapai hasil panen yang melimpah dan kesuburan tanahnya, mereka masih menggunakan suatu ritual maupun upacara-upacara yang berbau magis. Masyarakat setempat menyebutnya dengan namaSeblang.

Ritual Seblang ini tertulis secara resmi oleh pembantu pimpinan wilayah daerah tingkat ii (Kabupaten) di Kecamatan Glagah pada tahun 1930. Pada tahun tersebut tertulis bahwa telah terjadi bencana alam yang menyerang lereng gunung Ijenb hingga ke Desa Olehsari. Banyak hasil alam serta panen para warga Desa Olehsari yang hancur dan gagal akibat kurang bersahabatnya alam terhadap keberlangsungan hidup masyarakat Desa Olehsari. Oleh karena itu beberapa warga berinisiatif untuk mengajak semua masyarakat Desa Olehsari melaksanakan ritual Seblang agar pagebluk dan penyakit bisa segera diatasi dan keadaan desa menjadi aman, tentram, dan damai. Hal ini didasari bahwa masyarakat Desa Olehsari menganggap pada zaman dahulu terjadinya paceklik bisa jadi karena 
kurangnya keseimbangan antara alam dengan manusia.

\subsection{Prosesi dan Komponen dalam Ritual Seblang}

Seblang merupakan salah satu bentuk kepercayaan masyarakat Desa Olehsari yang berupa upacara keagamaan atau ritual keagamaan. Ritual itu sendiri merupakan tata cara dalam upacara atau suatu perbuatan keramat yang dilakukan oleh sekelompok umat beragama, yang ditandai dengan adanya berbagai macam unsur dan komponen, yaitu adanya waktu, tempat-tempat dimana ritual dilakukan, alat-alat dalam ritual, serta orang-orang yang menjalankan ritual (Heru). Komponen dan unsur yang terpenting dalam ritual Seblang adalah kejiman.

Kejiman merupakan suatu kegiatan dimana sang penari Seblang dalam keadaan tidak sadarkan diri oleh karena bagian dalam tubuhnya dimasuki oleh roh leluhur atau dahnyang. Hal ini bisa terjadi karena roh tersebut ingin berkomunikasi langsung dengan masyarakat guna memberikan informasi tentang kapan dilangsungkannya ritual hingga pemilihan penari Seblang berikutnya. Kemudian komponen terpenting lainnya adalah omprok.

Omprok merupakan sebuah mahkota yang terbuat dari daun pisang muda dan terbuat dari bahan alami berupa dedaunan seperti pupus daun pisang, pupus daun pinang, daun nanas, dan daun jambu serta bunga-bunga yang berada di Desa Olehsari yang digunakan ketika penari Seblang melakukan aksinya. Dalam hal ini, omprok juga bisa berfungsi sebagai obat dalam menyembuhkan berbagai macam wabah penyakir serta sebagai bahan dalam bercocok tanam yang dapat menimbulkan kesuburan.

\subsection{Dampak Sosial dan Budaya Pelaksanaan Ritual Seblang Terhadap Masyarakat Desa Olehsari}

Sepanjang perjalanan sejarah, kehidupan keritualan sebagai bagian dari kebudayaan tidak pernah lepas dari perubahan. Hal ini terjadi karena perkembangan pola pikir dan pemahaman manusia terhadap lingkungan dan apa yang ada di sekitarnya, atau karena percikanpercikan dengan unsur lain yang ada di luar dirinya. Sejalan dengan berjalannya waktu, maka ritual pun hanyut dalam pasang surutnya dinamika budaya. Nilainilai sosial dan budaya masyarakat Osing tepatnya di Desa Olehsari ini terhitung masih perawan jika dibandingkan dengan desa yang lainnya. Olehsari termasuk kedalam golongan desa yang kebudayaannya telah dirawat dengan baik, karena seluruh elemen warganya selalu memberikan dan mendukung sesuatu dengan rasa semangat tanpa pamrih, terutama dalam hal kegiatan keritualan. Keterikatan dan kesadaran antara manusia dengan alam semesta, dapat menciptakan suatu hubungan yang seimbang antara manusia dengan alamnya, sehingga terbangun keadaan yang aman, terjaga, dan terlindungi. Hal tersebut sekaligus dapat menyampaikan pemikiran bersama antar masyarakat desa Olehsari, yakni akan adanya satu kesatuan sosial.

Menjalankan dan merayakan ritual Seblang bagi masyarakat desa Olehsari tidak hanya sebagai tuntutan akan warisan para leluhur, melainkan juga menjaga dan menjalankan amanat generasi penerus, khususnya yang memiliki garis genetis penari Seblang. Generasi keturunan Seblang inilah yang menjadi pihak atau komunitas yang paling bertanggung jawab atas keeksistensian ritual Seblang. Keberadaan ritual Seblang yang telah 
tertanam begitu kuat dipikiran masyarakat desa Olehsari, menjadikannya juga sebagai bahan perekat dalam rasa saling memiliki antar sesama dan berbagi dalam hal apapun.

Produk budaya lokal Banyuwangi telah mengalami proses yang cukup lama dan panjang, sepanjang perjalanan sejarah Blambangan sebagai kerajaan Hindu terakhir diujung timur pulau Jawa, sebab sebelum menjadi bagian dari kerajaan Majapahit, Blambangan tidak pernah lepas dari incaran kerajaankerajaan lain yang tertarik dengan kondisi geografis yang strategis dan subur. Serangkaiaan hubungan dan penaklukan oleh kerajaan lain menyebabkan masyarakat memiliki pola budaya tersendiri sebagai masyarakat multi etnik yang mampu mengolah keragaman budaya

\section{Simpulan}

Berdasarkan uraian dari pembahasan di atas, maka akan diuraikan mengenai kesimpulan permasalahan yang dikaji dalam penelitian ini yaitu :

a) Ritual Seblang merupakan sebuah ritual yang dilaksanakan oleh masyarakat Desa Olehsari sebagai ritual bersih desa dan tolak bala. Selain itu juga, masyarakat Desa Olehsari menganggap bahwa ritual ini banyak mengundang sesuatu hal yang positif, baik dari segi kehidupan sosialnya, hubungan manusia dengan lingkungannya, serta hubungan manusia dengan Sang Penciptanya. Menurut keyakinan masyarakat Desa Olehsari, melalui ritual inilah pesanpesan tersebut bisa tersampaikan

b) Ritual Seblang mampu menunjukkan penanda identitas komunitas masyarakat Osing, karena telah menjadi satu-satunya ritual bersih desa yang dilaksanakan oleh masyarakat Osing di Desa Olehsari.
Dengan adanya ritual ini, orang Osing khususnya masyarakat Desa Olehsari, akan mudah mengenali dan menghafal siapa-siapa saja warga desa yang merupakan satu lingkup komunitas Osing. Meskipun jarak rumah yang jauh maupun yang berada diperantauan, akan tetapi rasa cinta pada kampung halaman dan sifat komunal yang sangat kuat, saudara satu suku, hal ini yang membuat mereka tidak akan pernah lupa bahwa Seblang yang menjadikan mereka hidup berdampingan dan saling menjaga keharmonisan antar warga satu dengan yang lainnya. Hal ini lah yang menjadikan kekuatan Seblang sebagai satu-satunya ritual perdamaian bagi masyarakat Osing dan terkhusus bagi masyarakat Desa Olehsari

\section{Daftar Pustaka}

Mufiani, Iftahuul. (2015). Mitos Mbah Bregas Di Dusun Ngino Desa Margoagung Seyegan Sleman Yogyakarta (Studi Terhadap Klasifikasi, Pandangan Dan Fungsi Mitos). Jurnal Religi. Vol. 11, No. 2; Juli, pp $17-45$.

Toyo, Hasbullah. (2017). Ritual Tolak Bala Pada Masyarakat Melayu (Kajian Pada Masyarakat Petalangan Kecamatan Pangkalan Kuras Kabupaten Pelalawan). Jurnal Ushuluddin. Vol. 25, No. 1; Januari-Juni, pp 83-100.

Jufri, Muhammad. (2017). Tradisi Ritual Seblang Dalam Perspektif Hukum Islam Di Desa Olehsari Kecamatan Glagah Banyuwangi. Jurnal Lisan Al-Hal. Vol 9, No. 1; Juni, pp 5-24. 
Widya, Diatyka. (2010). Tradisi, Ekonomi-Politik, dan Toleransi Yogyakarta. Jurnal Sosiologi. Vol. 15, No. 25; Juli, pp 37-60.

Lies, Indah. (2017). Tradisi Masyarakat Selo dan Pariwisata di Taman Nasional Gunung Merbabu, Boyolali Jawa Tengah. Jurnal SASDAYA, Gadjah Mada Journal of Humanities. Vol. 1, No. 2; Mei, pp 199-208.

Cathrin, Shely. (2017). Tinjauan Filsafat Kebudayaan Terhadap Upacara Adat Bersih-Desa Di Desa Tawun, Kecamatan Kasreman, Kabupaten Ngawi, Jawa Timur. Jurnal Filsafat. Vol. 27, No. 1; Februari, pp 30-64.

Saputra, Heru (2014). Wasiat Leluhur: Respons Orang Using terhadap Sakralitas dan Fungsi Sosial Ritual Seblang. Jurnal Makara Hubs-Asia. 18(1), 53-65. DOI: 10.7454/mssh.v18i1.3461.

Kholil, Ahmad (2010). Seblang Dan Kenduri Masyarakat Desa Olehsari: Relasi Ideal Antara Islam Dan Budaya Jawa Di Banyuwangi. Jurnal El-Harakah. Vol. 12. No. 2, pp 131-153.

Ahmad, Sutarto. (2003). Etnografi masyarakat Using. Laporan Penelitian, Universitas Negeri Jember.

Kuntowijoyo. (2003). Metodologi Sejarah: Edisi Kedua. Yogyakarta: Tiara Wacana.

Margana, Sri. (2012). Ujung Timur Jawa 1763-1813: Perebutan Hegemoni Blambangan. Yogyakarta: Pustaka Ifada.
Sjamsudin, Helius. (2007). Metodologi Sejarah. Yogyakarta: Ombak.

Munawarroh, Avina. (2016). Upacara Adat Bakaua. Thesis, Universitas Negeri Andalas.

Betty, Andrew. (1996). Syncretism in the Javanese Slametan. Jurnal Anthropological Institute. Vol. 2.

Subagyo, H. (2003). Bentuk Dan Makna Simbolik Tari Seblang Di Desa Olehsari Kabupaten Banyuwangi Jawa Timur. Jurnal Greget. Vol. 2. No. 2, pp 27-45. 